Images in Mind 



\section{Images in Mind}

STATUES IN ARCHAIC AND CLASSICAL GREEK LITERATURE AND THOUGHT

Deborah Tarn Steiner 
Copyright (C) 2001 by Princeton University Press

Published by Princeton University Press, 41 William Street, Princeton, New Jersey 08540

In the United Kingdom: Princeton University Press, 3 Market Place, Woodstock, Oxfordshire OX20 1SY

All Rights Reserved

Second printing, and first paperback printing, 2003

Paperback ISBN 0-691-09488-8

The Library of Congress has cataloged the cloth edition of this book as follows

Steiner, Deborah, 1960-

Images in mind : statues in archaic and classical Greek literature and thought / Deborah Steiner. p. cm.

Includes bibliographical references and index.

ISBN 0-691-04431-7 (alk. paper)

1. Greek literature-History and criticism. 2. Statues in literature. 3. Art and literature-Greece. 4. Sculpture in literature. 5. Aesthetics, Ancient.

6. Statues-Greece. 7. Sculpture, Greek. I. Title.

PA3015.S82 S74 2001

$880.9^{\prime} 357-\mathrm{dc} 21$

00-057463

British Library Cataloging-in-Publication Data is available

This book has been composed in Sabon

Printed on acid-free paper. $\infty$

www.pupress.princeton.edu

Printed in the United States of America

$\begin{array}{lllllllll}10 & 9 & 8 & 7 & 6 & 5 & 4 & 3 & 2\end{array}$ 